EXPLORING THE COMPOSITION OF THE PENTATEUCH 


\title{
BULLETIN FOR BIBLICAL RESEARCH SUPPLEMENTS
}

\author{
Editor \\ Richard S. Hess, Denver Seminary \\ Associate Editor \\ Craig L. Blomberg, Denver Seminary \\ Advisory Board
}

Leslie C. Allen

Fuller Theological Seminary

Donald A. Carson

Trinity Evangelical Divinity School
Donald A. Hagner

Fuller Theological Seminary

Bruce K. Waltke

Knox Theological Seminary 


\section{Exploring the Composition of the Pentateuch}

EDITED BY L. S. BAKER JR., KENNETH BERGLAND, FELIPE A. MASOTTI, AND A. RAHEL WELLS 


\section{Library of Congress Cataloging-in-Publication Data}

Names: Baker, Leslie Scott, Jr., editor. | Bergland, Kenneth, editor. | Masotti, Felipe A., editor. | Wells, A. Rahel (Abigail Rahel), editor.

Title: Exploring the composition of the Pentateuch / edited by L.S. Baker Jr., Kenneth Bergland, Felipe A. Masotti, and A. Rahel Wells.

Other titles: Bulletin for biblical research supplements.

Description: University Park, Pennsylvania : Eisenbrauns, [2020] | Series: Bulletin for biblical research supplement series | Includes bibliographical references and index.

Summary: "A collection of revised papers from a 2016 conference at Andrews University, exploring new ideas about the composition of the Pentateuch that arise from analysis of the biblical text"-Provided by publisher.

Identifiers: LCCN 2020020I74 | ISBN 978I575069852 (hardback)

Subjects: LCSH: Bible. Pentateuch-Authorship_Congresses. | Bible. PentateuchCriticism, interpretation, etc.-Congresses.

Classification: LCC BSI225.52 .E97 2020| DDC 222/.I066-dc23

LC record available at https://lccn.loc.gov/2020020I74

Copyright (C) 2020 The Pennsylvania State University

All rights reserved

Printed in the United States of America

Published by The Pennsylvania State University Press,

University Park, PA I6802-I003

Eisenbrauns is an imprint of The Pennsylvania State University Press.

The Pennsylvania State University Press is a member of the Association of University Presses.

It is the policy of The Pennsylvania State University Press to use acid-free paper. Publications on uncoated stock satisfy the minimum requirements of American National Standard for Information Sciences - Permanence of Paper for Printed Library Material, ANSI Z39.48-I992. 